\title{
THE EFFECT OF IMPORT FACILITIES FOR EXPORT PURPOSES, EXCHANGE RATES, AND INFLATION ON EXPORTS OF TEXTILES AND TEXTILE PRODUCTS
}

\author{
Indah Puspitasari ${ }^{1}$ \\ Mohammad Fachrudin, S.E., M.M. ${ }^{2}$ \\ 1,2 Polytechnic of State Finance STAN, Indonesia \\ 1) Email: mahrus08@gmail.com \\ ${ }^{2)}$ Email: dosen.kepabeanan@gmail.com
}

\section{ARTICLE INFORMATION}

Received date

[11-09-2020]

Revision

[18-12-2020]

Accepted date

[22-12-2020]

\begin{abstract}
:
The Import Facility for Export Purpose (KITE) is the Government's effort to encourage export performance. Companies that receive the KITE facility obtain fiscal incentives and export their product to import raw materials. The textile and textile product (TPT) industry is a strategic industry and has been determined by the Government as a pilot industry in the Roadmap for Making Indonesia 4.0. The textile industry relies on imported raw materials, so that the KITE facility is needed to encourage growth and increase product competitiveness in the international market. This study aims to determine the effect of the KITE facility, the rupiah exchange rate against the U.S. dollar, and the inflation rate on Indonesia's textile exports. We used a sample of 37 industrial textile companies in Indonesia that received the KITE facility 2016 to 2018. This study uses a panel data regression model with independent variables: KITE facility, exchange rates, inflation, and exported dependent variable. The results showed that the KITE facility had a positive and significant effect on the textile industry exports. In contrast, the exchange rate and inflation had a negative and significant impact on Indonesia's textile industry exports. This study's implications for the Government can be used to formulate a national strategy to increase export.
\end{abstract}

Keywords: Export, KITE, exchange rate, inflation, textile and textile products 


\section{INTRODUCTION}

One of the economic indicators that can be observed is the trade balance, which is the difference between exports and imports of a country in a certain period. The trade balance is used to measure all international transactions. The trade balance can experience two conditions, namely the trade balance surplus and deficit. A trade balance surplus occurs when the export value exceeds the country's import value, while the trade balance deficit when the import value exceeds the export value of a nation.

As depicted in Graph 1, Indonesia's Exports and Imports, the trade balance is a surplus due to the export value increased in 2017 by $16.28 \%$ compared to 2016 . The trade balance deficit in 2018 occurred due to an increase in imports, namely $20.21 \%$ from 2017, which was not matched by the rise in export value, which only increased by $6.62 \%$ compared to 2017 .

Graph 1. Indonesian Exports and Imports

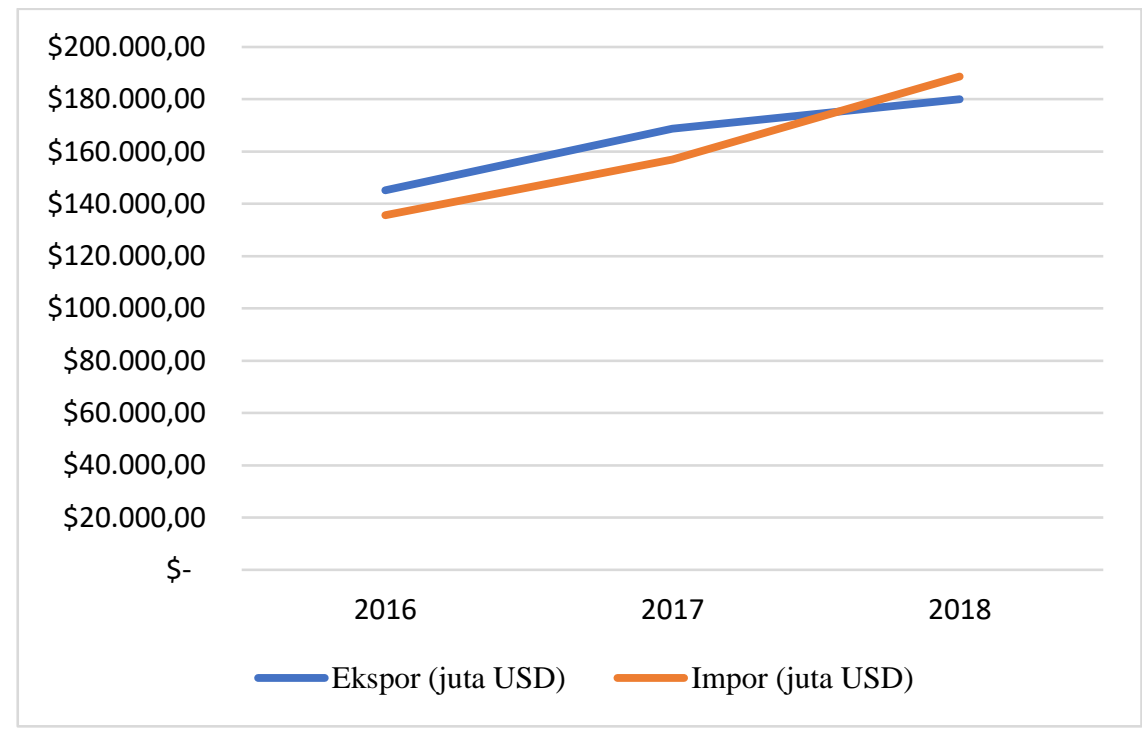

Source: BPS, compiled by the Ministry of Trade (2019)

The unsatisfactory export performance prompted the Government to pursue economic growth from the export side. One of the efforts made is to provide incentives in the Ease of Import for Export Purposes (KITE), mandated by the Directorate General of Customs and Excise (DGCE). This is in line with DGCE's vision as a world-leading institution in the customs and excise sector and its mission to facilitate trade and industry.

The Import Facility for Export Purpose (KITE) consists of facilities for exemption from import duty, value-added import tax (PPN), and Luxury Goods on Sales Tax (PPnBM) levied on imports of raw materials whose products are for export as regulated in PMK 176/PMK.04/2013 as well as facilities for returning import duties on imported raw materials, whose products are for export as regulated in PMK 177/PMK.04/2013. This facility is given to 
various industrial business entities with export and already has a NIPER (Company Registration Number).

According to the Hecksher-Olin theory in Darwanto (2009), a country will export products with high production factors. With a large population, Indonesia has a high factor of labor production. One of the textile industry's strategic industries and textile products (TPT) work (labor-intensive). President Joko Widodo in Beritagar (2019) stated that the domestic textile industry is one of the five large industries that contributed to the highest gross domestic product (GDP) in the second quarter of 2019 , namely $1.3 \%$.

However, according to the Chairman of the Association of Indonesian Textile Experts (IKATSI), Suharno Rusdi in Industry (2019), currently, the Indonesian textile industry is in bad condition due to a flood of imported goods from abroad so that it is difficult for local industries to find a market to sell their products. The flood of imported goods impacts production products that settle and do not sell so that companies force to reduce production capacity and lay off thousands of workers. In this case, the export-oriented textile industry has the advantage of having a more extensive opportunity and market abroad. Therefore, government incentives through the Facility of Import for Export Purposes (KITE) are needed to encourage growth and increase the textile industry's selling power aimed at exports.

Fiscal facilities have the opportunity cost, namely eliminating state revenues from the tax side. Therefore, the KITE facility provided must have an optimal impact on the Indonesian economy. The research is interested in finding out whether the KITE facility can comply with its increasing export of the Indonesian textile industry. The export and import of textile raw materials for the textile industry carry out in foreign currencies, significantly U.S. dollars. Inflation affects the prices of domestic goods in general, which affects production costs. Therefore, this study aims to determine whether the KITE facility, the rupiah exchange rate against the U.S. dollar, and Inflation affect the textile industry's export value in Indonesia.

According to research by Nabila and Sriyanto (2018), using a replication of Aritonang's (2005) research model, KITE facilities have a significant effect on exports. In their research, Pratiwi et al. (2012) stated that KITE facilities and the rupiah exchange rate significantly impact export value in Central Java. Research by Nagari and Suharyono (2017) and Lestari (2011) shows that the exchange rate and Inflation have a significant effect on Indonesia's textile exports. 


\section{LITERATURE REVIEW AND HYPOTHESIS DEVELOPMENT}

\subsection{Literature Review}

\subsubsection{The Hecksher-Ohlin (H-O) model}

In Darwanto (2009), the Hecksher-Ohlin theory or The Proportional Factors Theory coined by Eli Hecksher and Berti Ohlin is the cause of differences in productivity between countries' differences in ownership of production factors by each country. A country will export goods with high factor ownership and low costs, while imports will carry out products with fewer production factors and high costs.

\subsubsection{The Law of Supply and Demand}

Demand and supply simultaneously drive the economy. In Suparmoko (2011), demand is the goods and services that you want to buy to meet the needs at various price levels and specific periods. According to the law of demand, when a good or service price increases, the demand for that good or service decreases; when there is a decrease in the price of a good or service, the demand will increase, assuming the other factors are constant.

Offers are goods and services available for sale at various price levels and specific periods. In the law of supply, when the price of a good or service rises, the supply will also increase; and when the price of a good or service falls, supply will fall, assuming the other factors are constant.

\subsubsection{Overview of the Indonesian Textile and Textile Product Industry (TPT)}

According to Hermawan (2008), at the end of 1980 to early 1990, world textiles and textile products began to involve Southeast Asia, including Indonesia. Textiles and textile products are classified according to the harmonized system (H.S.) and cording to trade commodities, namely the Standard International Trade Classification (SITC).

Based on the Organization for Economic Co-operation and Development in Hermawan (2008), the textile industry supply chain describes into five parts, namely:

a. the network of raw materials, namely natural and synthetic fibers;

b. network components by the textile industry, for example, yarns and fabrics;

c. production network by garment;

d. trade network; and

e. retail-level marketing network.

To enter the era of the industrial revolution 4.0 through the Roadmap for Making Indonesia 4.0, the Government through the Ministry of Industry in 2018 has appointed five domestic industries as pilot industries, one of which is the textile industry. The textile industry is a very strategic industry for the Indonesian economy that it needs to facilitate so that it can 
continue to grow and develop and be competitive in the international world, both through fiscal and non-fiscal incentives.

\subsection{Hypothesis}

\subsubsection{The Effect of KITE Facilities on Exports}

According to Krugman (2000), the factors that influence export demand are export prices, real exchange rates, global income, and devaluation. Factors that affect export supply are export prices, domestic prices, actual exchange rates, production levels, imports of raw materials, and revaluation.

Indonesia always encourages a trade balance surplus to drive the national economy by boosting export performance, including fiscal policy. The KITE facility provides incentives for exempted import duties and free import taxes, and refundable import duties related to importing raw materials for products for export purposes. In the macroeconomic model, the research results by Batavia and Nandakumar (2017) referred to export subsidies, and the reduction of import tariffs shows that both export subsidies and import tariff reductions can boost exports.

In the research of Nabila and Sriyanto (2018) with the replication of the Aritonang model (2005), the value of KITE facilities has a positive effect on export values by cutting production costs from Import Duty and Taxes in Import (PDRI) of raw materials so that the prices of goods are lower and competitive global. If the demand for the export of these goods is price elastic, so a decrease in price causes a high increase in order, the increase in the value of exports will be definite. It does not follow the decline in prices in demand, and it could have an impact on decreasing export value. According to research by Pratiwi et al. (2012), KITE facilities have a positive effect on exports in Central Java. Based on these studies, this study uses the KITE facility variable to test whether the value of the KITE facility affects the exports of the Indonesian textile industry so that the first hypothesis is:

H1 = KITE facilities significantly affect textile industry companies' export value, whose imports of raw materials take advantage of KITE facilities in Indonesia.

\subsubsection{The Effect of Exchange Rates on Exports}

The exchange rate or exchange rate is the value of a country's currency compared to other countries' currencies. The variable that uses is the rupiah exchange rate against the U.S. dollar. According to Mankiw (2012), when the currency exchange rate appreciates, the country's export products' price in the eyes of the world will increase, thereby reducing demand for its export products. Meanwhile, if the rupiah exchange rate depreciates, the price of the country's export products in the eyes of the world will be lower, thereby increasing demand for its export products. Pratiwi et al. (2012) stated that the rupiah exchange rate had a negative effect on the 
value of exports, whose imports of raw materials received KITE facilities in the Central Java region. This study uses the rupiah exchange rate variable against the U.S. dollar to test whether the rupiah exchange rate against the USD affects the exports of the Indonesian textile industry that receive KITE facilities so that the second hypothesis is:

$\mathrm{H} 2$ = The rupiah exchange rate against the U.S. dollar has a significant adverse effect on textile industry companies' export value that receives KITE facilities.

\subsubsection{Inflation Effect on Exports}

Inflation causes an increase in the prices of goods and services, which affects the amount of demand and supply. Nagari and Suharyono (2017) state that inflation has a positive and significant effect on textile exports. This result is supported by Lestari's (2011) research, which states that inflation has a significant positive effect on Indonesian textile exports. This study uses the inflation variable to test whether inflation affects the exports of the Indonesian textile industry, which receive KITE facilities so that the third hypothesis is:

$\mathrm{H} 3$ = Inflation has a positive and significant effect on textile industry companies' export value that receives KITE facilities.

\section{RESEARCH METHODS}

This research approach uses a quantitative approach with panel data analysis of textile industry companies in Indonesia that obtained KITE facilities in the 2016-2018 timeframe. This study uses secondary data from the Directorate General of Customs and Excise and the Central Bureau of Statistics with the following research models:

$$
\ln (\mathrm{EKSP})=\alpha+\beta_{1} \ln (\mathrm{KITE})+\beta_{3} \ln (\mathrm{KURS})+\beta_{4}(\mathrm{INFL})+\varepsilon
$$

The variables analyzed above include the following limitations:

a. EKSP $=$ The export value of the textile industry company for finished goods with imported raw materials that get KITE facilities for one-year

b. KITE $=$ Value of KITE facilities (exemption and return) given to TPT industrial companies for one year

c. KURS = Rupiah exchange rate against USD in one-year

d. $\mathrm{INFL}=$ Indonesia's inflation rate in one year

The method of selecting research samples through purposive sampling. Sugiyono (2016) states that purposive sampling is a selection method that does not allow each population to be sampled. The study population was companies holding NIPER that received KITE facilities from the TPT industry. The population is 64 companies, 55 companies for KITE exemptions, and9 companies for KITE returns. As depicted in Figure 1, the exports of textile and textile 
industry companies that utilized the KITE facility in 2016 reached 11.6\%; for 2017, it was $5.7 \%$, and in 2018 it was $6.2 \%$ of the total exports of Indonesian textiles and textile products.

Figure 1. Comparison of the Export Value of the TPT Industry for KITE Facility Recipients

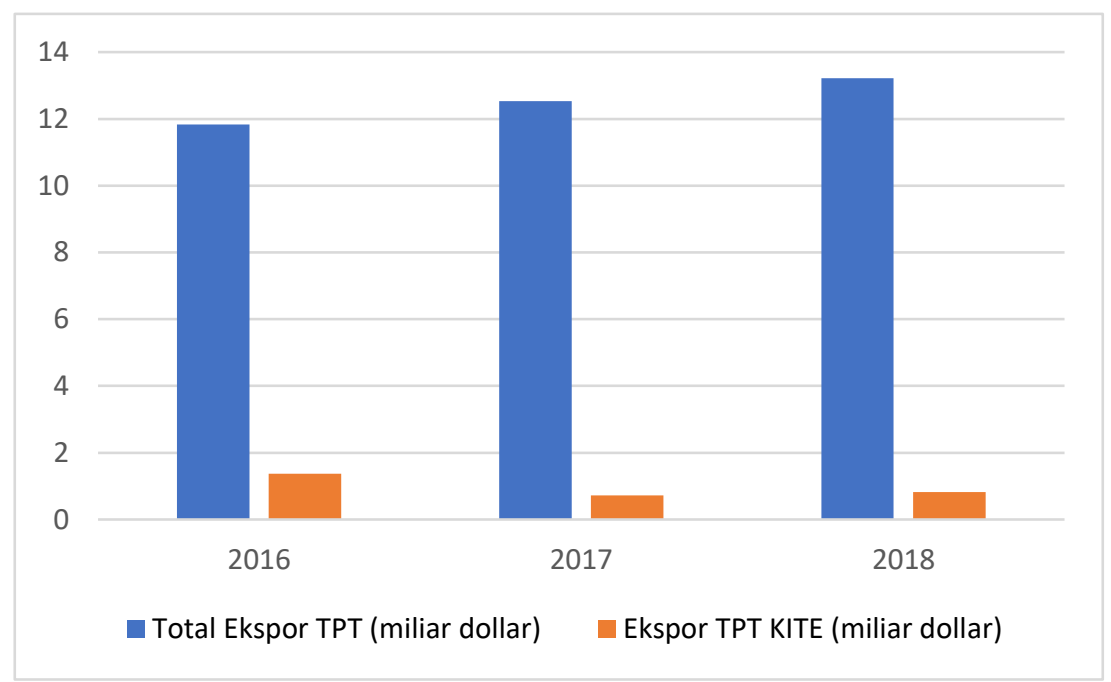

Source: BPS and DGCE (2019), compiled by the author

The development of the KITE facility value from 2016 to 2018 showed in Graph 3 Value of the Textile and Textile Product KITE Facility. The value of KITE facilities for this industry decreased in 2017 compared to 2016. Based on DGCE data (2019), the value of KITE facilities in the TPT industry increased significantly again in 2018 due to an increase in the number of raw materials imports and an increase in the number of companies receiving KITE facilities from the TPT industry Indonesia.

The development of the KITE facility value from 2016 to 2018 showed in Graph 2 Value of the Textile and Textile Product KITE Facility. The value of KITE facilities for this industry decreased in 2017 compared to 2016. Based on DGCE data (2019), the value of KITE facilities in the TPT industry increased significantly again in 2018 due to an increase in the number of raw materials imports and an increase in the number of companies receiving KITE facilities from the TPT industry Indonesia.

The sample criteria have complete data on the value of KITE facilities and exports for the 2016 to 2016 period. 2018 so that the observed variables can be measured. The population is 64 companies. There are 27 companies with incomplete data, so this sample showed selected as many as 37 companies. All company data (cross-section) have the same observation year, three years (time series) from 2016 to 2018 so this research has 111 observations. 
Graph 2. Value of TPT Industrial KITE Facilities

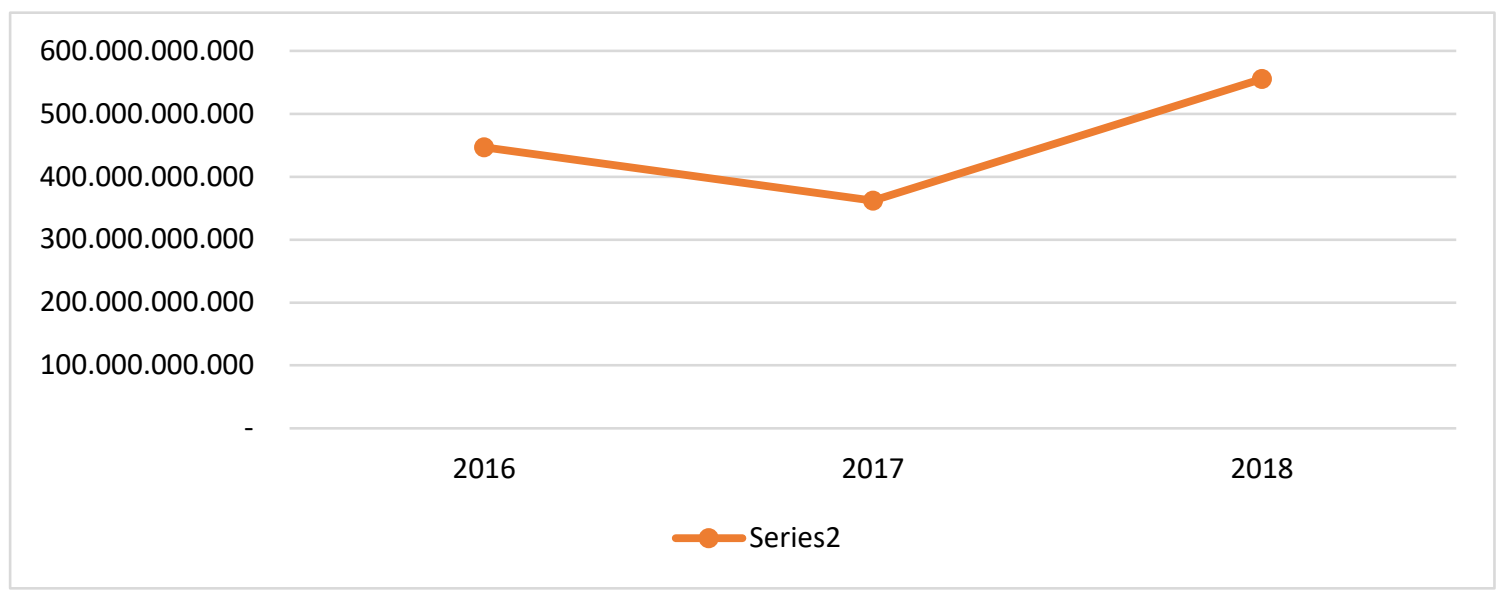

Source: DGCE (2019), compiled by the author

\section{DISCUSSION}

\subsection{Description of Research Data}

Empirical research states a logarithmic form relationship in the export model (Anggawijaya, 2008). Therefore, the authors transformed the EXPORTS variable data as the dependent variable and the KITE and KURS variables as independent variables into a natural logarithm form (ln). According to Gujarati (2009), the natural logarithmic form (ln) causes the panel data regression coefficient to value elasticity. The concept of elasticity is useful in knowing the quantitative measure of the response of something to changes in the factors that influence it.

The INFLATION variable in this study is not transformed into a natural logarithm (ln) because the data for this variable is in the form of a percentage and can be negative (deflation). Hence, the model in this study is a semi-log model (Junaidi, 2015).

\subsection{Selection of Panel Data Regression Approach}

\subsubsection{Chow test}

The selection of the smallest conventional approach or fixed effect approach is through the Chow test with the following hypotheses:

H0: The lowest usual approach

H1: Fixed effects approach

$\mathrm{H} 0$ is rejected if the probability $\mathrm{F} \leq \alpha=5 \%$

The test results with the Eviews 9.0 application show a probability F of 0.0000 . The probability of $\mathrm{F}$ is lower than $\alpha=5 \%$, so that $\mathrm{H} 0$ is rejected. That is, the fixed-effect approach $\mathrm{H} 1$ is chosen. 
Table 1. Chow Test Results

\begin{tabular}{|c|c|c|c|}
\hline Effects Test & Statistic & d.f. & Prob. \\
\hline Cross-section F & 3.998852 & $(36,71)$ & 0.0000 \\
\hline Cross-section Chi-square & 122.962013 & 36 & 0.0000 \\
\hline
\end{tabular}

Source: Processed with the Eviews 9.0 application

\subsubsection{The Hausman Test}

The fixed effect approach was chosen from the previous test results, and then the Hausman test was carried out with the hypothesis:

H0: Random effects approach

H1: Fixed effects approach

$\mathrm{H} 0$ is rejected if the probability $\leq \alpha=5 \%$

The test results show that F's probability is 1.0000 , which exceeds $\alpha=5 \%$, meaning that $\mathrm{H} 0$ is accepted, so the random effects approach was chosen.

Table 2. Hausman Test Results

\begin{tabular}{|l|l|l|l|}
\hline & Chi-Sq. Statistic & Chi-Sq. d.f. & Prob. \\
\hline Cross-section random & 0.000000 & 3 & 1.0000 \\
\hline
\end{tabular}

Source: Processed with the Eviews 9.0 application

By choosing the random-effects approach based on the results of the two tests above, this research model is:

$$
\ln (\text { EKSP })_{\text {it }}=\alpha+\beta_{1} \ln (\text { KITE })_{\text {it }}+\beta_{3} \ln (\text { KURS }) \text { it }+\beta_{4}(\text { INFL }) \text { it }+\left(\mu_{\mathrm{i}}+\varepsilon_{\text {it }}\right)
$$

\subsection{Hypothesis Testing}

In panel data analysis, the model must meet the BLUE (Best Linear Un] Estimator) requirements, meaning that the model must pass classical assumptions violations. This study's model has passed the classical assumption test to be used in the panel data regression test.

Based on the regression results, the coefficient of determination (R2), the results of the F-test (simultaneous), and the results of the t-test (partial) are:

Table 3. Panel Data Regression Test Results

\begin{tabular}{|c|c|c|c|}
\hline Variable & Coefficient Std. Error & t-Statistic & Prob. \\
\hline LOG(KITE) & \begin{tabular}{ll|l|l|l}
0.880346 & 0.020446 \\
\end{tabular} & 43.05661 & 0.0000 \\
\hline LOG(KURS) & \begin{tabular}{|l|l|}
-0.316747 & 0.026609 \\
\end{tabular} & -11.90381 & 0.0000 \\
\hline INFL & \begin{tabular}{|l|l|}
-0.226445 & 0.001793 \\
\end{tabular} & -126.2651 & 0.0000 \\
\hline $\mathrm{C}$ & \begin{tabular}{l|l|}
-0.547504 & 0.196813 \\
\end{tabular} & -2.781854 & 0.0064 \\
\hline \multicolumn{2}{|c|}{ R-squared } & 0.638426 & \\
\hline \multicolumn{2}{|c|}{ Adjusted R-squared } & 0.628289 & \\
\hline \multicolumn{2}{|c|}{ F-statistic } & 62.97622 & \\
\hline \multicolumn{2}{|c|}{ Prob(F-statistic) } & 0.000000 & \\
\hline
\end{tabular}

Source: Processed with the Eviews 9.0 application 


\subsubsection{Test the coefficient of determination}

This test assesses the model's ability to explain variations in the independent variables. The coefficient will be 0 s.d. 1 . If the $\mathrm{R} 2$ value is small, then the independent variable's ability to explain the dependent variable is low. If $\mathrm{R} 2$ approaches 1 , the independent variable can explain the dependent variable more reliably. Ghozali (2016) states that the use of R2 is biased because when the independent variable increases, the R2 value will also increase regardless of whether the independent variable is significant or not. The use of adjusted R2 is more recommended if the study uses more than one independent variable.

Based on the test results on the model above, adjusted R2 is worth 0.628289 or $62.83 \%$. The combination of the independent variables in this study affected the value of the dependent variable EXPORT by $62.83 \%$, while the remaining $37.17 \%$ came from factors outside the study.

\subsubsection{F-test (simultaneous)}

Simultaneous $\mathrm{F}$ testing aims to determine the effect of the independent variable $(\mathrm{X})$ together on the dependent variable $(\mathrm{Y})$ with the hypothesis:

H0: all independent variables in the study simultaneously do not affect the export variable

H1: all independent variables in the study simultaneously affect the export variable

$\mathrm{H} 0$ is rejected if the probability $\leq \alpha=5 \%$

Based on the test results above, the probability F-statistic is 0.000000 , which is lower than $\alpha=5 \%$, so that $\mathrm{H} 0$ is rejected, meaning that the independent variables consisting of KITE, KURS, and INFLATION variables simultaneously have a significant effect on the EXPORT variable at the level of confidence up to with $\alpha=5 \%$.

\subsection{3. t-test (partial)}

Partial t-test to determine whether the independent variables have a significant effect on the dependent variable with the following hypothesis:

$\mathrm{HO}$ : the independent variable partially does not have a significant effect on the export variable

H1: the independent variable partly has a significant effect on the export variable

$\mathrm{H} 0$ is rejected if the probability $\leq \alpha=5 \%$

The test results on the KITE, KURS, and INFLATION variables show a probability tstatistic of $0.0000 \mathrm{ich}$ is less than $\alpha=5 \%$. This means that each independent variable has a significant effect on the EXPORT variable. 


\subsubsection{Panel Data Regression Equations}

Based on the regression results above, the formulation of this research model is:

$$
\begin{gathered}
\ln (\mathrm{EKSP})_{\text {it }}=-\mathbf{0 . 5 4 7 + 0 . 8 8 0} \ln (\mathrm{KITE})_{\text {it }}-0.317 \ln (\text { KURS })_{\text {it }}-\mathbf{0 . 2 2 6} \\
(\text { INFL }) \text { it }+\left(\mu_{\mathrm{i}}+\varepsilon_{\text {it }}\right)
\end{gathered}
$$

The interpretation of the panel data regression results above is as follows:

a. The constant $(\alpha)$ has a regression coefficient of -0.547 . If the value of all independent variables is 0 , then the export value is -0.547 . According to Dougherty (2002), the constant value can be ignored as long as it meets the classical assumption test. Gujarati (2009) that the intercept value does not always have meaning because the independent variable's range does not involve zero as the observed value.

b. $\beta 1$ KITE variable coefficient with an elasticity value of 0.880 . A positive sign $(+)$ on the KITE variable's coefficient indicates that if the KITE variable increases, the EXPORT variable will also increase. The elasticity value of the KITE variable is 0.880 , showing that every $1 \%$ increase in the value of the KITE facility provided to the textile industry companies increases their export value by $0.880 \%$, assuming other factors remain.

c. $\quad \beta 2$ The coefficient of the KURS variable with an elasticity of -0.317 . The negative sign () in the KURS variable coefficient means that if the rupiah exchange rate against the U.S. dollar strengthens, exports will decline. The elasticity value of the KURS variable is 0.317 . This means that every $1 \%$ strengthening of the rupiah exchange rate against the U.S. dollar will reduce the textile industry exports by $0.317 \%$ if other factors are constant.

d. $\beta 3$ The coefficient of the INFLATION variable with an elasticity of -0.226 . The negative sign (-) in the inflation variable coefficient means that exports will decline when the inflation rate increases. This variable has an elasticity value of 0.226 . This means that every $1 \%$ increase in Inflation will reduce the textile industry's export value by $0.226 \%$ if other factors are constant.

The random-effects approach produces a constant value (intercept) of 37 pieces representing each sample company. The constant value difference shows how much other factors outside the model affect each company's export size.

\subsection{Discussion}

\subsubsection{The effect of KITE facilities on exports}

The first hypothesis (H1) is that KITE facilities significantly affect textile industry companies' export value, whose imports of raw materials take advantage of KITE facilities in Indonesia. The result of the t-test (partial) is that the KITE facility positively and significantly 
affects the textile industry exports. This means that if the KITE facility's value increases, Indonesia's textile industry exports will also increase. Therefore, the first hypothesis is accepted.

The value of the KITE facility consists of the value of import duty and value-added tax and sales tax of luxury goods in the context of import, which is not collected, and import duty that is refunded on the import of raw materials for the company receiving the KITE facility. Companies that receive KITE facilities are export-oriented. The Indonesian textile industry relies on imported raw materials from abroad. Chairman of the Indonesian Textile Association (API), Ade Sudrajat, in Beritagar (2019) stated that e cost of importing raw materials is one of the burdensome components and weakens the competitiveness of the domestic textile industry in the global realm.

The price of production factors negatively affects the level of supply (Mankiw, 2018). Lower production costs have prompted producers to increase their production levels because the profit margins that will be obtained by producers will be even later. The provision of KITE facilities plays a significant role in reducing production costs in raw material import costs. In PMK No. 6 / PMK.010 / 2017, the import duty rates imposed on imports of raw materials for the textile industry range from a minimum of $0 \%$ to a maximum of $15 \%$. Meanwhile, when using luxury goods as raw material, the PPnBM rate is $15 \%$ to $75 \%$. Therefore, exemption from import duty s well as PPnBM not collected through the KITE facility will have a significant effect on cutting production costs for raw material components. The reduction in production costs due to the KITE facility received by export-oriented companies can allow producers to expand their market for export purposes at competitive selling prices.

The import VAT rate is $10 \%$ of the import value. In VAT, the mechanism for input tax and output tax. In export-oriented companies, the input tax in importing raw materials is VAT paid in import activities. The VAT will then be charged to the selling price of the goods produced, while the output tax is the VAT contained in the exported goods. Input Tax is credited with tax output in the same tax period. If the input tax exceeds the output tax, the difference is compensated for the next tax period. However, the payment of VAT at import will burden the company's cash flow, thereby reducing its ability to increase its competitive ability (Anggawijaya, 2008). The ease of fiscal facilities in tax exemptions in the flow will affect the company's finances (Gumilar, 2015). Therefore, in addition to lower the selling price with free import VAT, companies receiving KITE facilities can also use their cash flow to increase production capacity instead of paying taxes. 
The Government continues to strive to increase national exports from the supply side to accommodate the business. Business developments, one of which is by improving policies related to KITE facilities, with the issuance of the latest KITE exemption regulations to PMK Number 160 / PMK.04 / 2018 related to Exemption of Import Duty and Free Taxes Value added or value-added tax and the sales tax on luxury goods on imported goods and materials to be processed, assembled, or installed on other goods for export; As for the policy regarding a return, KITE is regulated in PMK Number 161 / PMK.04 / 2018 concerning Returns of Import Duty Paid on Imported Goods and Materials to be Processed, Assembled, or Installed on Other Goods for Export Purpose, which is valid from 18 February 2019.

One of the factors that influence demand is the price of these goods (Rahardja, 2008). An increase in the price of goods will reduce the demand for these goods, while a decrease in the price of goods will increase the demand for these goods. According to Nabila and Sriyanto (2018), KITE exports are sensitive to price decreases. Therefore, competitive prices will increase the demand from the international market. Based on Warta Ekonomi (2019) API data, the world textile industry is dominated by China products, which are known to have industry and very competitive prices. The lower the production cost, the more competitive the price will be to compete in the international market, so that it is expected to increase the demand for exports of Indonesian textiles and textile products. Efforts to increase export demand must also be balanced with efforts to expand the market. From Figure 4, Export Destination Countries for Indonesian Apparel, which are examples of Indonesia's textile products, the United States is the largest export destination country. The President of the United States, Donald Trump, in Whitehouse (2018) marked the start of a trade war with China, which resulted in the products of each country being unable to enter the markets of the two countries. It is an excellent opportunity for Indonesia to increase its exports to the United States market in line with the increasing demand to meet U.S. textiles and textile products' needs. Thus, through fiscal incentives, government support, one of which is through KITE facilities, is needed in these opportunities.

Efforts to increase export demand can also target non-traditional export destination countries with high potentials, such as the African region, to expand the Indonesian textile industry market in the global real. 
Graph 3. Main Export Destination Countries for Indonesian Apparel

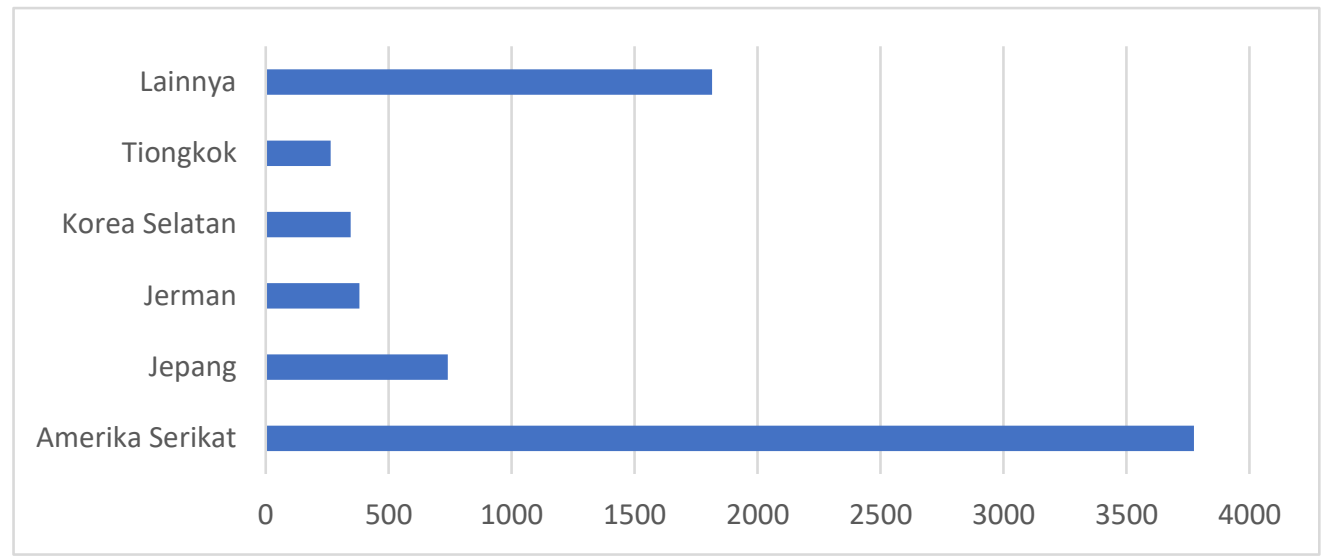

Source: Processed from BPS data (2019)

Referring to Figure 1 Comparison of the Export Value of the TPT Industry for KITE Facility Recipients, the export value of KITE facility recipients only reaches 5-6\% of the total national textile industry exports. It is necessary to study further the factors that cause the number of companies, and the contribution of the export value of KITE facility recipients to the textile industry is still low.

The provision of KITE facilities, on the other hand, has the opportunity cost of eliminating potential state revenue. Therefore, it is necessary to ensure that KITE facilities provide optimal benefits for domestic strategic industries by carrying out supervision so that fraud does not occur in their implementation.

\subsubsection{The effect of exchange rates on exports}

The second hypothesis $(\mathrm{H} 2)$ of this study is that the rupiah exchange rate against the U.S. dollar has a negative and significant effect on textile industry companies' export value in Indonesia that receive KITE facilities. The result of the t-test (partial) states that the KURS variable has a significant negative effect on exports in Indonesia's textile industry. This means that if the rupiah exchange rate depreciates, the exports of textile industry companies in Indonesia that receive KITE facilities will increase. Therefore, the second hypothesis is accepted.

The exchange rate will have an impact on imports and exports (Case and Fair, 2007). The rupiah's depreciating exchange rate has caused the price of textiles and textile products from Indonesia to e low for foreign markets. Thus, potentially increasing export demand from international markets. Meanwhile, if the rupiah exchange rate appreciates, it will cause the price of textiles and textile products from Indonesia to increase, thus potentially reducing the demand for exports of Indonesian textiles and textile products. According to the law of demand, a decrease in the price of a good increases demands, and vice versa. This study's results are 
consistent with the research of Pratiwi et al. (2012), namely that the exchange rate has a significant negative effect on exports whose imports of raw materials receive KITE facilities in the Central Java region.

From the supply side, an increase in the price of goods will increase supply, and on the contrary, (Suparmoko, 2011). International trade transactions are carried out using foreign currencies, namely U.S. dollars. The depreciation of the rupiah exchange rate has caused producers to export to get higher profits, thus encouraging producers to increase their exports. If the rupiah exchange rate appreciates, producers exporting will lower profits, thus encouraging producers to reduce their exports.

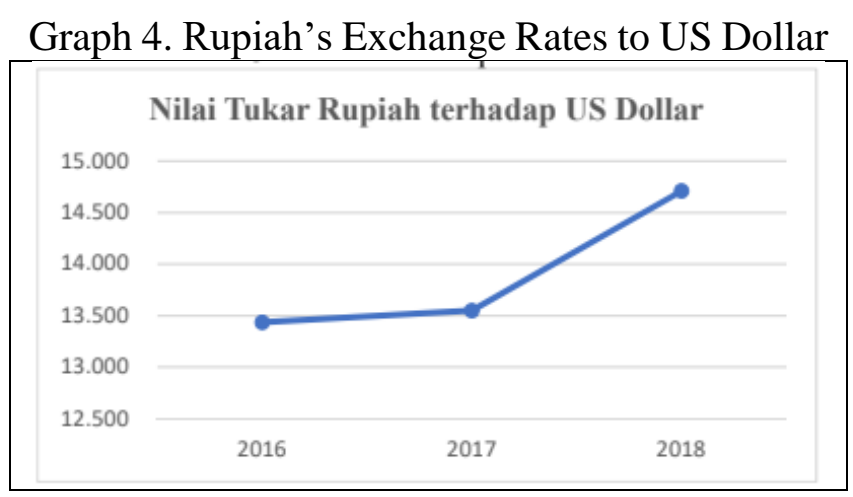

Source: Processed from BPS data (2019)

Referring to Figure 1 Comparison of the Export Value of the TPT Industry for KITE Facility Recipients and Graph 4 Exchange Rates during 2016 to 2018, we can see that the depreciation of the rupiah value there is an increase in exports of textile goods and textile products.

\subsubsection{The effect of Inflation on exports}

The third hypothesis (H3) is that Indonesia's inflation rate has a significant positive effect on textile industry companies' export value that receive KITE facilities. The partial test results (t-test) state that the inflation variable negatively and significantly affects exports in Indonesia's textile industry. This means that if the inflation rate increases, the exports of the textile industry companies that receive KITE facilities will experience a decline. Thus, based on the research results, the third hypothesis is rejected.

Inflation has resulted in an increase in domestic prices in general. It is following Sukirno (2004) who states that Inflation can cause high production costs in the country so that the selling price will be higher and it will be challenging to compete in the international market. Although the Indonesian textile industry's primary raw materials are mostly imported from abroad, other components of production costs are still obtained domestically. According to Ravi Shankar, Chair of the Association of Indonesian Fiber and Filament Yarn Manufacturers (APSYFI), one 
of the high-cost components is Beritagar (2019) is energy costs due to the high price of industrial gas in Indonesia. This resulted in high production costs and goods prices, which resulted in lower export demand for the Indonesian textile industry.

On the supply side, the price of production factors affects supply (Mankiw, 2018). The high price of production factors causes producer profits to decrease due to this reducing export supply to the Indonesian textile industry.

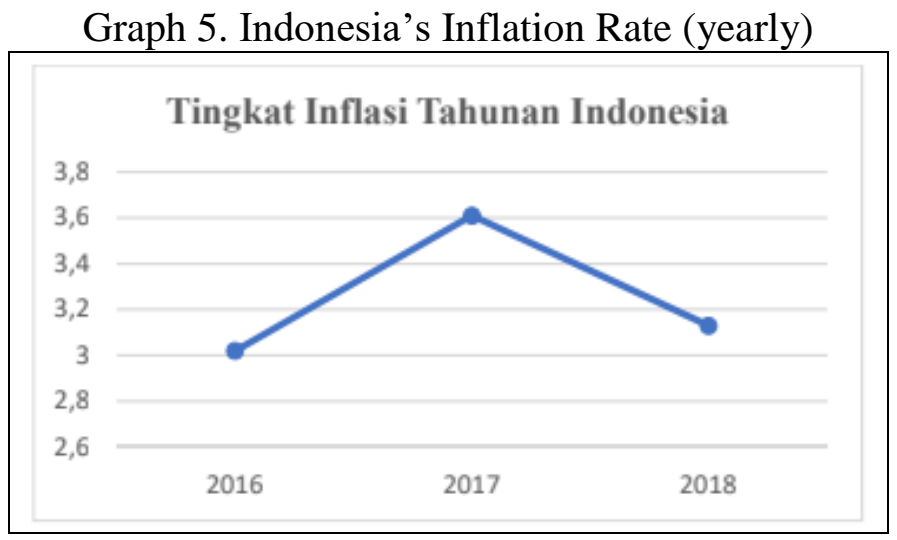

Source: Processed from BPS data (2019)

Referring to Figure 1 Comparison of the Export Value of the TPT Industry for KITE Facility Recipients, and Graph 5 Inflation during 2016 to 2018 we can see that the increase or decrease in inflation does not affect exports of textile goods and textile products.

\section{CONCLUSION AND POLICY RECOMMENDATIONS}

\subsection{Conclusion}

The results of this study indicate:

1) KITE facilities have a significant positive effect on textile industry companies' export value, whose imports of raw materials take advantage of KITE facilities in Indonesia at a $95 \%$ confidence level with an elasticity level of $0.880 \%$. In the textile industry that relies on raw materials from abroad, the KITE facility can reduce the cost of importing raw materials and encourage an increase in export value.

2) The rupiah exchange rate against the U.S. dollar has a significant adverse effect on the export value of textile industry companies in Indonesia that receive KITE facilities at a confidence level of $95 \%$ and an elasticity level of $0.317 \%$. The depreciation of the rupiah exchange rate against the U.S. dollar causes the price of textiles and textile products from Indonesia to be low in other countries' eyes, thereby increasing the demand for textiles and textile products from Indonesia. Meanwhile, the appreciation of the rupiah exchange rate against the U.S. dollar has made Indonesian textiles and textile products expensive abroad, thus reducing the demand for textiles and textile products from Indonesia. 
3) Indonesia's inflation rate has a significant adverse effect on the export value of textile and textile product companies that receive KITE facilities at a 95\% confidence level with an elasticity level of $0.227 \%$. Inflation causes high domestic production costs, so that the selling price will be higher, and it will be challenging to compete in the international market.

\subsection{Policy Recommendations}

This study's results have implications for determining government policies to attract investment in the form of fiscal incentives, in this case, that KITE. KITE are useful instruments for governments to increase textile and textile product export. The most important thing is maintaining the KITE facilities for the textile and textile product industry to competitiveness their product in the global market.

\section{REFERENCES}

Boediono. (1985). Ekonomi Moneter Edisi 3. Yogyakarta: BPFE.

Case, Karl E. \& Ray, C Fair. (2007). Prinsip-Prinsip Ekonomi. Jakarta: Erlangga

Dougherty, C. (2002). Introduction to econometrics. 2nd ed. New York: Oxford University Press.

Ghozali, I. (2016). Aplikasi Analisis Multivariate dengan Program IBM SPSS 21. Semarang: Badan Penerbit Universitas Diponegoro.

Gujarati, Damodar. (2009). Basics Econometrics, $5^{\text {th }}$ Edition. London: McGraw-Hill. Hsiao, Cheng. (1992). Analysis of Panel Data. New York: Cambridge University Press. Junaidi. (2015). Bentuk Fungsional Regresi Linear (Aplikasi Model dengan Program SPSS). Keynes, John M. (1936). The General Theory of Employment, Interest, and Money. London: Macmillan.

Krugman, P. (2000). International Economics; Theory and Policy. Boston: Addison-Wesley. Lewis, W. Arthur. (2003). Theory of Economic Growth. Abingdon-on-Thames: Routledge. Mankiw, N. G. (2009). Macroeconomics, 7th Edition. New York: Worth Publishers.

Mankiw, N. G. (2018). Principles of Economics, 8th Edition. Boston: Cengage Learning. Nachrowi, Nachrowi \& Usman, Hardius. (2006). Pendekatan Populer dan Praktis Ekonometrika Untuk Analisis Ekonomi dan Keuangan. Jakarta: LP FEUI.

Rahardja, Pratama \& Manurung, Mandala. (2008). Pengantar Ilmu Ekonomi (Mikroekonomi \& Makroekonomi) Edisi Ketiga. Jakarta: FEUI.

Ricardo, David. (1817). On the Principles of Political Economy and Taxation. London: John Murray.

Ruslan, Kadir. (2012). Model dengan Autokorelasi, Kenapa Tidak?

Smith, Adam. (1776). The wealth of Nations. London: W. Strahan and T. Cadell.

Sugiyono (2016). Metode Penelitian Kuantitatif, Kualitatif, dan R\&D. Bandung: Alfabeta.

Sukirno, S. (2004). Makroekonomi teori pengantar. Jakarta: PT Raja Grafindo Persada.

Suparmoko, M. (2011). Teori Ekonomi Mikro Edisi 1. Yogyakarta: BPFE.

Widarjono, Agus. (2007). Ekonometrika Teori dan Aplikasi. Yogyakarta: Ekonisia.

Anggawijaya, I., \& Susila, G. N. (2008). Pengaruh Pembebasan dan/atau Pengembalian Bea

Masuk serta Pajak Dalam Rangka Impor tidak Dipungut Terhadap Nilai Ekspor dalam Skema Fasilitas KITE (Studi Kasus Terhadap Perusahaan Teraktif pada Kantor Wilayah 
Direktorat Jenderal Bea dan Cukai Jakarta) (Doctoral dissertation, Tesis. Jakarta: Universitas Indonesia).

Aritonang, P. O. (2005). Analisa pengaruh pemberian fasilitas kemudahan impor tujuan ekspor (KITE) terhadap nilai ekspor Indonesia (Doctoral dissertation, FE-UI).

Asbiantari, D. R., Hutagaol, M. P., \& Asmara, A. (2018). Pengaruh Ekspor Terhadap Pertumbuhan Ekonomi Indonesia. Jurnal Ekonomi dan Kebijakan Pembangunan, 5(2).

Balassa, Bela. (1986). Policy Response to Exogeneous Shocks in Developing Countries. American Economics Review. 76(2).

Batavia, B., \& Nandakumar, P. (2017). The equivalence of export subsidies and import tariff reductions in a macroeconomic model. The Journal of Economic Asymmetries, 15, 76-80.

Darwanto. (2009). Model Perdagangan Hecksher-Ohlin (Teori, Kritik, dan Perbaikan). FE Undip.

Gumilar, G., Suyadi, I., \& Agusti, R. R. (2015). Pemanfaatan Fasilitas Kemudahan Impor Tujuan Ekspor (Kite) Untuk Meningkatkan Ekspor Dalam Negeri (Studi Pada Kantor Wilayah Direktorat Jenderal Bea Cukai Jatim I, Sidoarjo). Jurnal Perpajakan (JEJAK), $6(2)$.

Hermawan, I. (2008). Analisis Ekonomi Perkembangan Industri Tekstil dan Produk Tekstil (TPT) Indonesia. (Doctoral dissertation, Institut Pertanian Bogor).

Nabila, A., \& Sriyanto, A. (2018). Analisis Pengaruh Fasilitas Kite terhadap Nilai Ekspor (Studi Kasus Perusahaan Penerima Fasilitas Kite). Jurnal Perspektif Bea dan Cukai, 2(1).

Nagari, A. A., \& Suharyono, S. (2017). Pengaruh Tingkat Inflasi Dan Nilai Tukar Terhadap Ekspor Tekstil Dan Produk Tekstil Indonesia (Studi Pada Tahun 2010-2016). Jurnal Administrasi Bisnis, 53(1), 202-210.

Nawatmi, S., \& Nusantara, A. (1999). Generalized Least Square: Solusi Atas Gejala Heteroskedastisitas. Jurnal Bisnis dan Ekonomi.

Pratiwi, I., Sugiyanta, \& Suratno, A. (2015). Analisis pengaruh pemberian fasilitas kite (kemudahan impor tujuan ekspor) dan nilai tukar rupiah terhadap nilai ekspor di Jawa Tengah (Bachelor Thesis, Program Studi Administrasi Bisnis POLINES).

Lestari, Mey R. M. (2011). Analisis Faktor-Faktor Yang Memengaruhi Ekspor Tekstil Di Indonesia Tahun 2005-2009 (Doctoral dissertation, University of Muhammadiyah Malang).

Kementerian Perdagangan RI. (2019). Neraca Perdagangan Indonesia Total. Jakarta.

Direktorat Jenderal Bea dan Cukai. (2017). Buku Tarif Kepabeanan Indonesia 2017. Jakarta.

Direktorat Jenderal Bea dan Cukai. (2019). Nilai Fasilitas KITE Industri TPT Indonesia 20162018. Jakarta.

Direktorat Jenderal Bea dan Cukai. (2019). Nilai Ekspor Industri TPT Indonesia 2016-2018. Jakarta

Republik Indonesia. (2006). Undang-undang No. 17 Tahun 2006 jo. Undang-Undang Nomor 10 Tahun 1995 tentang Kepabeanan

Republik Indonesia. (2009). Undang-Undang Nomor 42 Tahun 2009 tentang Pajak Pertambahan Nilai Barang dan Jasa dan Pajak Penjualan Atas Barang Mewah

Kementerian Keuangan Republik Indonesia. (2013). Peraturan Menteri Keuangan 254/PMK.04/2011 jo. PMK 176/PMK.04/2013 Tentang Pembebasan Bea Masuk Atas Impor Barang Dan Bahan Untuk Diolah, Dirakit, Atau Dipasang Pada Barang Lain Dengan Tujuan Untuk Diekspor

Kementerian Keuangan Republik Indonesia. (2013). Peraturan Menteri Keuangan 253/PMK.04/2011 jo. PMK 177/PMK.04/2013 Tentang Pengembalian Bea Masuk Yang Telah Dibayar Atas Impor Barang Dan Bahan Untuk Diolah, Dirakit, Atau Dipasang Pada Barang Lain Dengan Tujuan Untuk Diekspor 
Kementerian Keuangan Republik Indonesia. (2018). Peraturan Menteri Keuangan Nomor 160/PMK.04/2018 tentang Pembebasan Bea Masuk dan Tidak Dipungut Pajak Pertambahan Nilai atau Pajak Pertambahan Nilai dan Pajak Penjualan atas Barang Mewah atas Impor Barang dan Bahan untuk Diolah, Dirakit, atau Dipasang pada Barang Lain dengan Tujuan untuk Diekspor

Kementerian Keuangan Republik Indonesia. (2018). Peraturan Menteri Keuangan PMK Nomor 161/PMK.04/2018 tentang Pengembalian Bea Masuk yang Telah Dibayar atas Impor Barang dan Bahan Untuk Diolah, Dirakit, atau Dipasang pada Barang Lain dengan Tujuan untuk Diekspor

Kementerian Keuangan Republik Indonesia. (2017). Peraturan Menteri Keuangan PMK Nomor 6/PMK.010/2017 tentang Penetapan Klasifikasi Barang dan Pembebanan Tarif Bea Masuk atas Barang Impor

Direktorat Jenderal Bea dan Cukai. (2014). PER-04/BC/2014 tentang Perubahan Atas Peraturan Direktur Jenderal Bea Dan Cukai Nomor Per-16/Bc/2012 Tentang Tata Laksana Pembebasan Bea Masuk Atas Impor Barang Dan Bahan Untuk Diolah, Dirakit, Atau Dipasang Pada Barang Lain Dengan Tujuan Untuk Diekspor

Direktorat Jenderal Bea dan Cukai. (2014). PER-05/BC/2014 Tentang Perubahan Atas Peraturan Direktur Jenderal Bea Dan Cukai Nomor Per-15/Bc/2012 Tentang Tata Laksana Pengembalian Bea Masuk Yang Telah Dibayar Atas Impor Barang Dan Bahan Untuk Diolah, Dirakit, Atau Dipasang Pada Barang Lain Dengan Tujuan Untuk Diekspor

Direktorat Jenderal Bea dan Cukai. (2019). PER-03/BC/2019 tentang Petunjuk Pelaksanaan Peraturan Menteri Keuangan Republik Indonesia Nomor 161/Pmk.04/2018 Tentang Pengembalian Bea Masuk Yang Telah Dibayar Atas Impor Barang Dan Bahan Untuk Diolah, Dirakit, Atau Dipasang Pada Barang Lain Dengan Tujuan Untuk Diekspor

Direktorat Jenderal Bea dan Cukai. (2019). PER-04/BC/2019 tentang Petunjuk Pelaksanaan Peraturan Menteri Keuangan Republik Indonesia Nomor 160/Pmk.04/2018 Tentang Pembebasan Bea Masuk Dan Tidak Dipungut Pajak Pertambahan Nilai Atau Pajak Pertambahan Nilai Dan Pajak Penjualan Atas Barang Mewah Atas Impor Barang Dan Bahan Untuk Diolah, Dirakit Atau Dipasang Pada Barang Lain Dengan Tujuan Untuk Diekspor

Beritagar. (2019). Impor Bahan Baku Jadi Beban Terbesar Industri Tekstil. https://beritagar.id/artikel/berita/impor-bahan-baku-jadi-beban-terbesar-industri-tekstil (diakses tanggal 15 Oktober 2019)

Bisnis.com. (2018). Tekstil Produk Tekstil Jadi Percontohan Industri 4.0. https://industri.bisnis.com/read/20180409/257/781836/tekstil-produk-tekstil-jadipercontohan-industri-4.0 (diakses tanggal 16 Oktober 2019)

BPS. (2019). Indeks Harga Konsumen dan Inflasi Bulanan Indonesia. https://www.bps.go.id/statictable/2009/06/15/907/indeks-harga-konsumen-dan-inflasibulanan-indonesia-2005-2019.html (diakses tanggal 31 Oktober 2019)

BPS. (2019). Ekspor Pakaian Jadi Konveksi dari Tekstil Menurut Negara Tujuan Utama. https://www.bps.go.id/statictable/2019/02/25/2026/ekspor-pakaian-jadi-konveksi-daritekstil-menurut-negara-tujuan-utama-2012-2018.html (diakses tanggal 22 Desember 2019)

BPS. (2019). Kurs Tengah Beberapa Mata Uang Asing terhadap Rupiah di Bank Indonesia. https://www.bps.go.id/dynamictable/2015/09/29\%2000:00:00/952/ kurs-tengahbeberapa-mata-uang-asing-terhadap-rupiah-di-bank-indonesia-dan-harga-emas-dijakarta-rupiah-2000-2017.html (diakses tanggal 31 Oktober 2019)

Industry. (2019). Ada Apa Industri Tekstil Nasional Pekerja Tekstil Minta Segera Diselamatkan. https://www.industry.co.id/read/54176/ada-apa-industri-tekstil-nasionalpekerja-tekstil-minta-segera-diselamatkan (diakses tanggal 16 Oktober 2019) 
Kadir Ruslan. (2012). Model dengan Autokorelasi, Kenapa Tidak? http://kadirsblog.blogspot.com/2012/06/model-dengan-autokorelasi-kenapa-tidak.html (diakses tanggal 6 Januari 2020)

Katadata. (2019). Inilah 10 Negara Tujuan Utama Ekspor Pakaian Jadi Indonesia. https://databoks.katadata.co.id/datapublish/2019/03/04/inilah-10-negara-tujuan-utamaekspor-pakaian-jadi-indonesia (diakses tanggal 3 Januari 2020)

Kementerian Perindustrian. (2013). Kebijakan Dorong Ekspor. https://kemenperin.go.id/artikel/7347/Kebijakan-Dorong-Ekspor- (diakses tanggal 19 Oktober 2019)

Kementerian Perindustrian. (2014). 64\% Dari Industri Nasional Bergantung Pada Bahan Baku Impor. https://kemenperin.go.id/artikel/9306/64-dari-Industri-Nasional-Bergantung-padaBahan-Baku-Impor (diakses tanggal 16 Oktober 2019)

Kompas. (2019). Kualitas Di Bawah Standar Produksi Jadi Alasan Indonesia Harus Impor. https://ekonomi.kompas.com/read/2019/01/11/084326826/kualitas-di-bawah-standarproduksi-jadi-alasan-indonesia-harus-impor?page=all (diakses tanggal 15 Oktober 2019)

Kompas. (2018). Sri Mulyani Inflasi 2017 Jauh Dibawah Prediksi. https://ekonomi.kompas.com/read/2018/01/02/193105326/sri-mulyani-inflasi-2017-jauhdi-bawah-prediksi (diakses tanggal 30 Januari 2020)

Tempo. (2018). Sri Mulyani Jelaskan Penyebab Rupiah Melemah Hingga Rp15.218. https://bisnis.tempo.co/read/1134222/sri-mulyani-jelaskan-penyebab-rupiah-melemahhingga-rp-15-218 (diakses tanggal 30 Januari 2020)

Wartaekonomi. (2019). Benah-Benah Industri Tekstil di Indonesia. https://www.wartaekonomi.co.id/read241144/benah-benah-industri-tekstilindonesia.html (diakses tanggal 19 Oktober 2019)

Whitehouse. (2018). Statement President Donald J. Trump Additional Proposed Section 301 Remedies. https://www.whitehouse.gov/briefings-statements/statement-president-donaldj-trump-additional-proposed-section-301-remedies/ (diakses tanggal 30 Januari 2020)

\section{APPENDIX \\ TEST RESULTS}

$\underline{\text { Multicollinearity Test }}$

\begin{tabular}{cccc}
\hline \hline & \multicolumn{2}{c}{ Coefficient } \\
Variance & $\begin{array}{c}\text { Uncentered } \\
\text { VIF }\end{array}$ & $\begin{array}{c}\text { Centered } \\
\text { VIF }\end{array}$ \\
\hline \hline LNKITE & 0.004187 & 119.9806 & 1.004095 \\
LNKURS & 2.607223 & 14244.64 & 1.076230 \\
INFL & 0.066276 & 43.19318 & 1.073825 \\
C & 244.4128 & 14675.40 & NA \\
\hline \hline
\end{tabular}

Autocorrelation Test

\begin{tabular}{llll}
\hline \hline R-squared & 0.638426 & Mean dependent var & 7.320997 \\
Adjusted R-squared & 0.628289 & S.D. dependent var & 1.094755 \\
S.E. of regression & 0.667451 & Sum squared resid & 47.66757 \\
F-statistic & 62.97622 & Durbin-watson stat & 1.540416 \\
Prob(F-statistic) & 0.000000 & & \\
\hline
\end{tabular}


White Period Robust Standard Error

White cross-section standard errors \& covariance (d.f. corrected)

\begin{tabular}{crrrr}
\hline \hline Variable & Coefficient & Std. Error & t-Statistic & Prob. \\
\hline \hline LNKITE & 0.880346 & 0.020446 & 43.05661 & 0.0000 \\
LNKURS & -0.316747 & 0.026609 & -11.90381 & 0.0000 \\
INFL & -0.226445 & 0.001793 & -126.2651 & 0.0000 \\
C & -0.547504 & 0.196813 & -2.781854 & 0.0064 \\
\hline \hline
\end{tabular}

Normality test

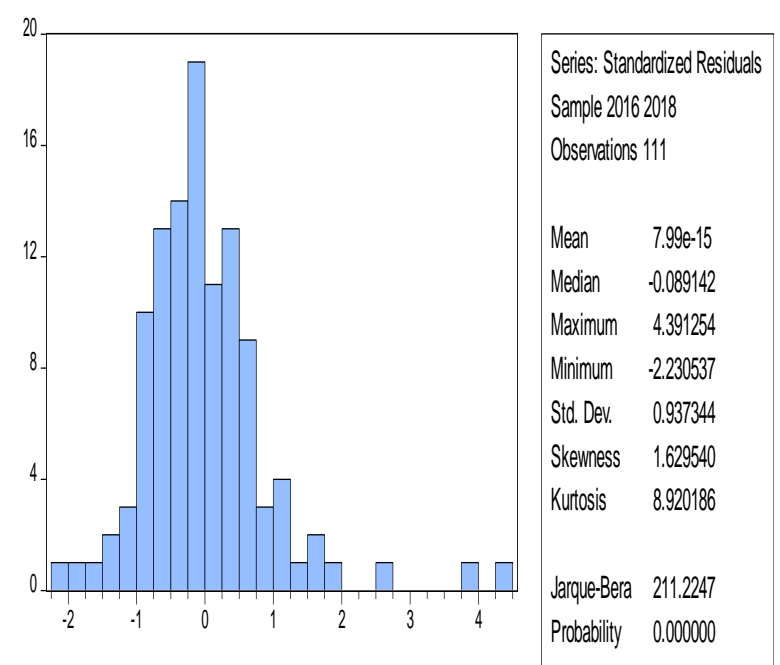

